\title{
Farming the future: Youth enthusiasm and transforming Nepal's economy through agriculture
}

\author{
Saugat Khanal ${ }^{\text {* }}$ and Pankaj Raj Dhital ${ }^{\mathrm{b}}$ \\ Agriculture and Forestry University
}

Stephen J. Christian ${ }^{\mathrm{c}}$

Lansing, New York

\begin{abstract}
Submitted July 13, 2020 / Revised September 10, October 10, October 24, and November 6, 2020 /
Accepted November 9, 2020 / Published online February 11, 2021

Citation: Khanal, S., Dhital, P. R., \& Christian, S. J. (2021). Farming the future: Youth enthusiasm and transforming Nepal's economy through agriculture. Journal of Agriculture, Food Systems, and Community

Development, 10(2), 359-372. https://doi.org/10.5304/jafscd.2021.102.027
\end{abstract}

Copyright (C 2021 by the Authors. Published by the Lyson Center for Civic Agriculture and Food Systems. Open access under CC-BY license.

\begin{abstract}
The authors conducted a study in December 2019 to investigate youth enthusiasm in Nepal for transforming the economy of the nation through farming. A total of 320 respondents from four towns in three districts were selected for interviews that used a pretested questionnaire. Descriptive statistics were employed to analyze the data. Most of the youth had positive perceptions and enthusiasm toward farming, but many felt that farming was "burdensome," due mainly to its perceived perception to provide only a low income.

a* Corresponding author: Saugat Khanal, Faculty of Agriculture, Agriculture and Forestry University, Bharatpur 44200,

Chitwan, Nepal, Bardaghat-13, Nawalparasi, Nepal; +9779861670088; ksaugat506@gmail.com

b Pankaj Raj Dhital, Assistant Professor, Department of Agricultural Extension and Rural Sociology, Agriculture and Forestry University, Chitwan, Nepal; prdhital@afu.edu.np

c Stephen J. Christian, Independent Editor, Lansing, New York 14882 USA; +1-607-379-2713; stphnchristian4@gmail.com
\end{abstract}

Almost half the respondents (45\%) were found to have a low level of contribution to economic transformation through farm involvement, with high (34\%) and medium (21\%) levels of contribution to the economy, respectively. There are several constraints hindering youth engagement with agriculture and overall agro-economic development. The major constraint is access to credit and markets, followed by poor social perception of farmers, inadequate government and extension service resources, access to modern technology, and other factors. The study authors recommend that the government and NGOs encourage youth engagement with agriculture by enhancing agricultural education, extension, financial support, and so forth. There is a need for extension program staff and policy-makers to better understand the role of youth in the community development process.

Funding Disclosure

Funding for this study was provided by Northern Illinois University's Research and Artistry Grant. 


\section{Keywords}

Agro-enterprises, Economy, Farming, Extension, Nepal, Youth, Beginning Farmers, Agricultural

Education

\section{Introduction}

Agriculture has been called the backbone of the national economy for the majority of developing countries (Lawal, 2011; Mogues, Yu, Fan, \& McBride, 2012). As $66 \%$ of the population of Nepal is directly engaged in farming, agriculture contributes to nearly $28 \%$ of total national GDP (Khanal \& Shrestha, 2019). The population is predominantly rural, and agriculture remains the primary occupation, with the majority of farmers engaged in subsistence agriculture. In the past, the scope of farming was limited to the production of crops and goods for human consumption. With the rapid advances in science and technology, however, the present scope of agriculture extends to areas such as macroeconomics, environmental science, forestry, aeroponics, and hydroponics. The significant potential for agricultural development in Nepal is predicated on rapid advancement in numerous fields of science and technology. Consequently, agricultural development means economic development.

No sector of a national economy can attain its intended level of development unless the involvement of youth is ensured (United Nations, 2008). Countries that are considered high economic achievers rely substantially on the continual efforts of youth (United Nations, 2018). It is vital to emphasize nurturing youthful knowledge and attracting skilled, capable youth to agriculture (Fatunla, 1996). Nevertheless, in developing countries most youth are highly apathetic toward agriculture (Adedoyin \& Jibowo, 2005). This has contributed to severe unemployment in the agriculture sector and a shortage of sustainable livelihood activities among youth (Breitenbach, 2006). However, youth in developing countries have different perspectives regarding the acceptability of farming. In the less developed countries of Africa, youth non-engagement in agribusiness has partly been ascribed to there being few attractive resources in agriculture and to disconnects between youth program offerings and vocational training and the actual require- ments of agricultural sectors (Aphunu \& Atoma, 2010; Nhamo \& Chikoye, 2017).

Because community development is a dynamic process involving all segments of the community, including the often-overlooked youth population, significant progress in farming could be achieved through youth involvement. Youth participation in organized groups facilitates their engagement in the community. As most Nepali youth are relatively disadvantaged in terms of access to skills and social capital, with little engagement with organizations, many regard farming as a 'no-go' area for career options. The perceived lack of techniques, experience, and knowledge in agriculture makes it less interesting to disadvantaged youth. Contemporary agriculture, transformed by globalized markets and new technologies, requires significant effort on the part of new farmers to gain skills necessary for success. Disadvantaged youth have less of the initiative required to succeed in this field. Some youths accept working in farming passively, largely due to originating from poor families, having deficient literacy, or having failed in other jobs (Chaudhary, 2018). Nepal's agriculture sector is experiencing manpower and entrepreneurship weaknesses because Nepali youth who have more initiative and drive often seek foreign employment (The Rising Nepal, 2014). Moreover, institutional efforts to involve youth in collective action at the execution phase of project management leave little space to negotiate the interests of youth (Gebremariam, 2017; Hartley, 2014; Proctor \& Lucchesi, 2012). The scientific and farming communities of Nepal need to realign the country's youth to cope with the bottlenecks arising while transforming economy through agriculture (Jabed, 2016).

The Nepali government is developing strategies and policies for youth-empowering programs (Hosein \& Yadav, 2017). Extension programs, basic farming education for youth, and other policies are being implemented to persuade youth to become more interested in farming. The government is developing financial, social, and technological tools and packages in collaboration with private agencies for helping youth in agriculture. However, despite agriculture's ample moneymaking potential for youth, challenges related 
specifically to youth involvement in farming and, more important, options for surmounting them are not extensively documented.

\section{Objectives}

The main objectives of the study were to understand the attitudes of youth toward agricultural work, assess their levels of enthusiasm, and explore how attitudes affect their potential contribution to the economy, in the area of Nepal on which the study focused. The specific objectives were to investigate the perceptions of youth toward agricultural production, describe the role of different agencies involved in youth development, examine the factors that attract youth to farming, and discuss the constraints limiting youth engagement in farming activities.

\section{Limitations of the Study}

Research on connecting youth with agriculture through their enthusiastic involvement is not a new approach, and we recognize that there are a number of potential limitations to our study. We sought to cover a larger area and involve more respondents than previous studies, but we acknowledge that we were not able to do so. The study was conducted in a small part of the country with a sample who was at least engaged in some kind of occupation related to agriculture. A detailed study with a larger area and a more representative sample from a wider range of vocations could be helpful for generalizing the results for all parts of Nepal. We were inexperienced with quantitative research tools that would enable us to fully analyze our data to answer our research questions. Even in terms of qualitative data, we did not capture as much information as we initially envisaged due to time limits and lack of funding.

\section{Youth and Economic Transformation}

Franklin D. Roosevelt said, "We cannot always build the future for our youth, but we can build our youth for the future" (The Franklin Delano Roosevelt Foundation, n.d.). This highlights how much value youth represents for economic transformation and what youth can do for nations when empowered to be agents of positive change. One major critique of youth empowerment is that most relevant official programs take a risk-focused approach, emphasizing what goes wrong with youth performance rather than what goes right. To youth, such an approach portrays development as a process of merely overcoming risk and may dissuade them from youth development programs (Guerra \& Bradshaw, 2008). The risk-based approach can obscure the reality that adolescence is a period when youth can master skills and ideas. Research suggests that invigorating youth with the idea of entrepreneurship in the farming sector enables the attainment of economic goals at community and national levels (Bruton, Ketchen, \& Ireland, 2013; Díaz-Pichardo, Cantú-González, López-Hernández, \& McElwee, 2012; Sinyolo \& Mudhara, 2018). Youth contributes significantly to land and agricultural reform, in turn sustaining youth enthusiasm (Gwanya, 2008). Largely because of their increased connectivity via social media and hence increased access to information, youth can conceive of ways to shape the economies around them in ways never possible before (Fletcher, 2019). Youth can be the driver of agribusiness, generating high returns on agricultural investment by using new ideas. In general, agribusiness does not mean just farming, but incorporates industries and services from farm production and processing to wholesale and retail, which can create youth job opportunities. Economic transformation, as used in this study, means a higher average income, broader diversity of economic enterprises, and greater contribution to GDP through agriculture produce surplus income (Allen et al., 2016; Leavy \& Smith, 2010; Roepstorff, Wiggins, \& Hawkins, 2011). Despite increasing recognition of the value of youth, too little is known about realizing the economic potential of youth for national development, thus slowing the pace of economic development.

\section{Youth Vision-2025 and Youth Unemployment}

Buckminster Fuller said, "You never change things by fighting the existing reality. To change something; build a new model that makes the existing model obsolete" (as quoted in Haber, 2007, p. 363). Keeping social and economic transformation central, Youth Vision-2025, approved by 
the Government of Nepal in 2015, aims at preparing youth for roles such as agricultural laborer, agro-businessperson, entrepreneur, and policymaker in order to change the nation from underdeveloped to rapidly developing within the next 10 years (Nepal Government Ministry of Youth and Sports, 2015). The plan stresses unity, equity, justice, harmony, and inclusion in order to enhance collaboration; it also focuses on the need to invest directly in youth for the economic progress of the country. The program also includes a Guarantee of Rights and Realization of Obligations, which encourages youth to work freely and independently.

However, Nepal is lagging behind other nations in providing youth employment that is sufficiently productive and remunerative, potentially imposing considerable, enduring economic and social costs (Raju \& Rajbhandary, 2018). As noted above, educated youth have a problem staying and working within the country due to the attraction of foreign employment with higher earnings. Every year many Nepali youths choose against their preference to leave the country for jobs or for higher education. Nevertheless, the youth unemployment rate of Nepal is decreasing in comparison to historical rates of unemployment. In 1999 , the youth unemployment rate was $2.93 \%$; in
2019, it fell to 2.14\% (Statistica, 2020). From 1999 to 2019 , the highest youth unemployment rate was $3.05 \%$, in 2003 (Statistica, 2020). The government has been successful in supporting unemployed youth, especially those engaged in farming, as a large portion of the annual national budget is allocated to agriculture. The youth unemployment rate from 1999 to 2019 is shown in Figure 1.

\section{Methodology}

The study was conducted in December 2019 in four communities in three districts of the southern lowlands of Nepal: Nawalparasi East, Nawalparasi West, and Chitwan (see Figure 2). A total of 320 youths, 15 to 35 , were selected randomly from the study areas. Interviews were conducted with the help of a questionnaire for both quantitative and qualitative information (see Table 1). Data was gathered in face-to-face interviews by using a pretested semi-structured questionnaire and by observation. Primary data was obtained through the key informant survey (KIS), questionnaire survey, focus group discussion (FGD), and an online survey with the respondents. The FGD involved gathering people from similar backgrounds or experiences together to discuss a specific topic of interest. The respondents were asked questions about their perceptions, attitudes,

Figure 1. Youth Unemployment Rate in Nepal, 1999-2019

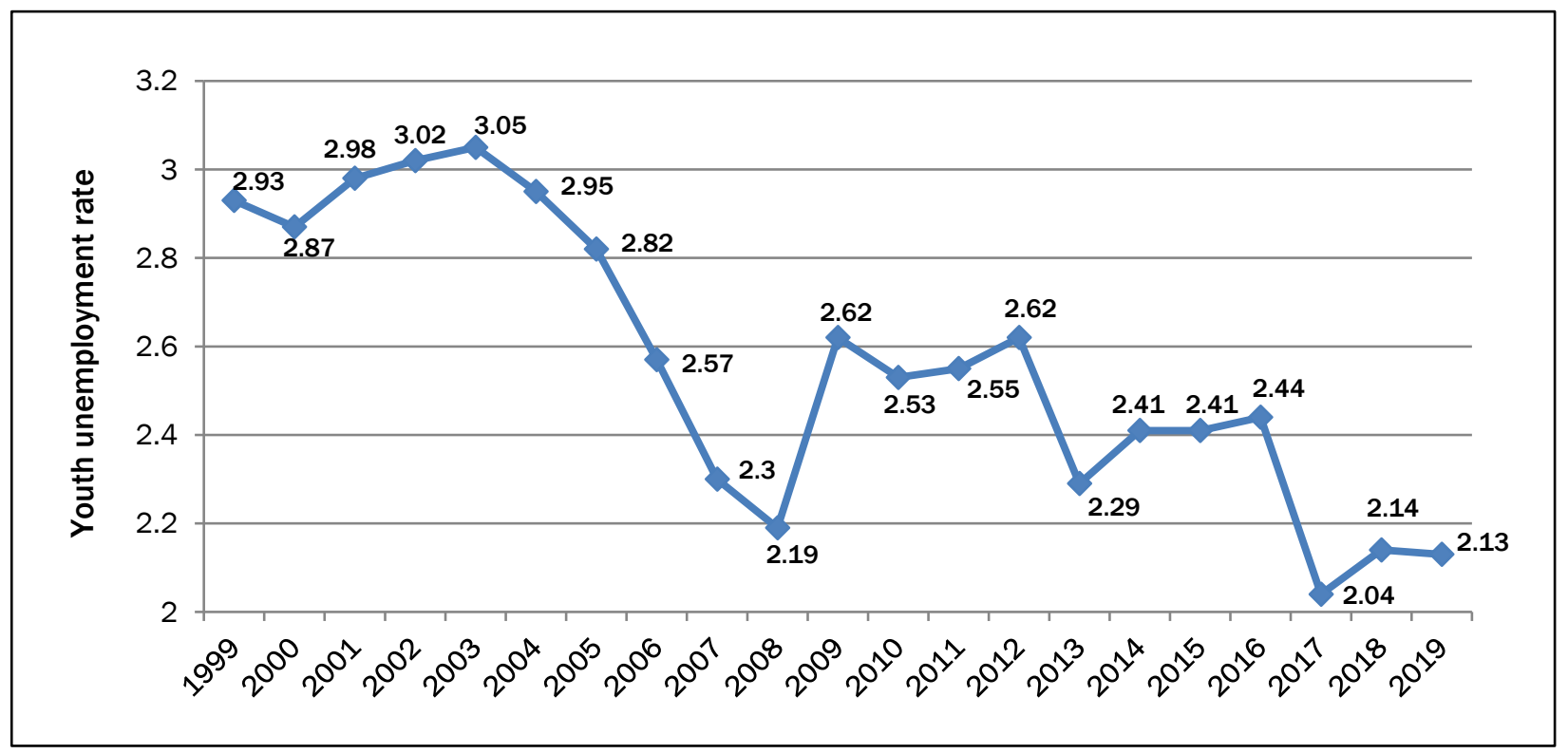

Source: Statistica, 2020. 
Figure 2. Study Areas

A. Study Areas in Nepal (Map prepared by Subodh Gyawali.)

B. Study Areas in Nawalparisi West and Nawalparisi East, Nepal

C. Study Areas in Chitwan District, Nepal
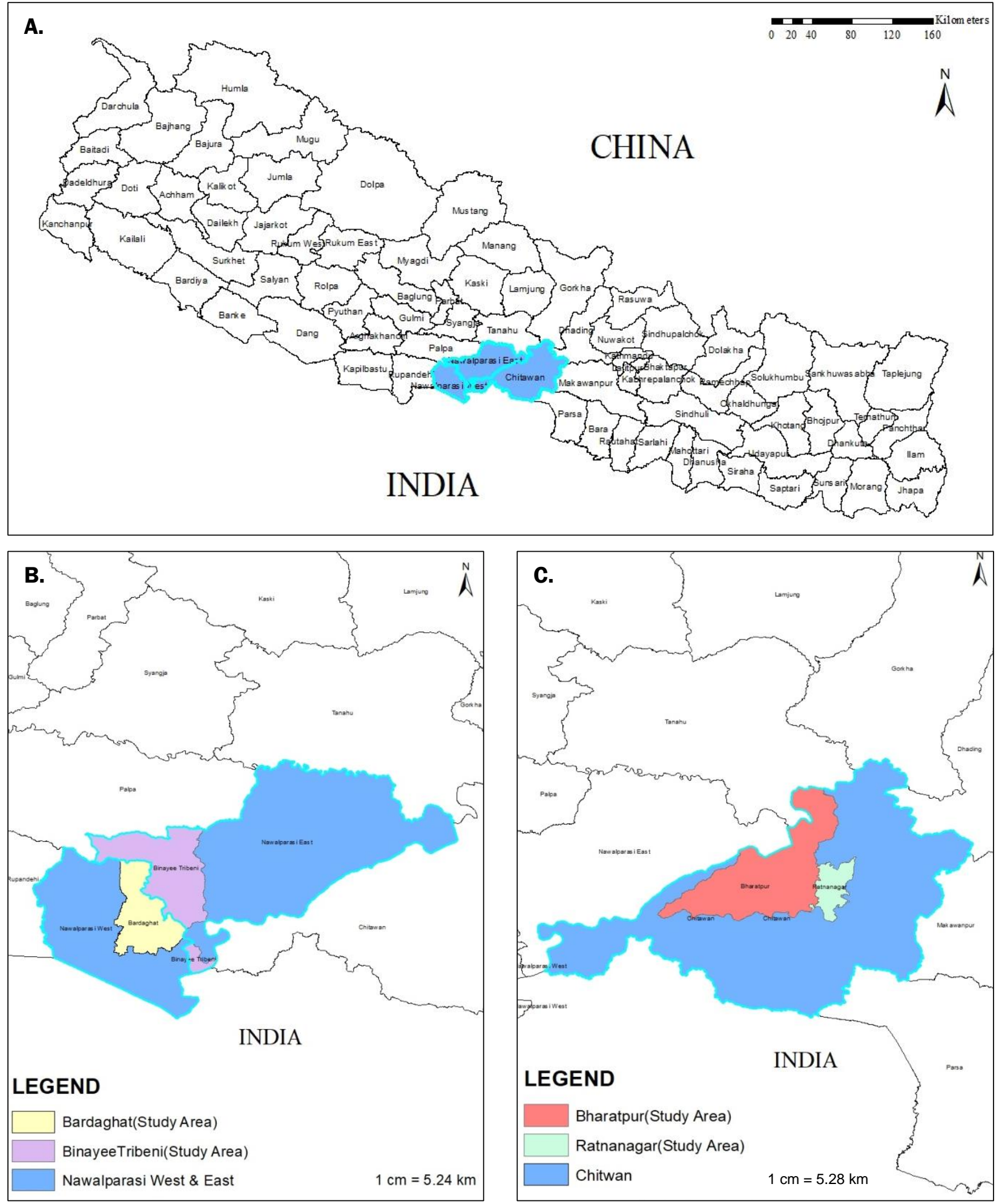
beliefs, opinions, and ideas. Secondary data was collected through the Youth Development Committee (YDC), Ministry of Youth and Sports (MYAS), Central Bureau of Statistics (CBS), annual reports, journals, etc. Information about the work of youth agencies and agricultural organizations in empowering youth were collected through YDC and MYAS, and the unemployment status of the youth population was assessed from CBS. Other related data was collected through reports, web pages, journals, and documents.

\section{Results and Discussion}

Socioeconomic Characteristics of the Respondents The majority $(81 \%)$ of the respondents were male (Table 2), which suggests that women's historic lack of rights to land ownership has hindered their engagement in agriculture. As in many traditional societies, women's rights to land and property have been unrecognized, and thus many women have been vulnerable by being almost entirely dependent on the men in their lives for basic economic survival. However, the Nepal government has been introducing several proactive measures to promote women's access, ownership, and control over land and property (International Organization for Migration, 2016).

About $64 \%$ of the respondents were in the age group 18-28. Most (78\%) of the individuals interviewed had received at least some secondary or postsecondary education; they were more educated than the average young Nepali. The nuclear family is dominant $(82 \%)$ and about $93 \%$ of the families have a male as the household head. The average monthly income of respondents was US\$220-

\section{Table 1. Sample Distribution in the Study Area}

\begin{tabular}{llccc}
\hline District & Area & Male [\# (\%)] & Female [\# (\%)] & Total [\# (\%)] \\
\hline Nawalparasi West & Bardaghat & $97(30.31)$ & $21(6.56)$ & $118(36.88)$ \\
\hline Nawalparasi East & Binayee Tribeni & $76(23.75)$ & $18(5.63)$ & $94(29.38)$ \\
\hline \multirow{2}{*}{ Chitwan } & Ratnanagar (Tandi) & $53(16.57)$ & $12(3.75)$ & $65(20.31)$ \\
\cline { 2 - 5 } & Bharatpur (Baseni) & $34(10.63)$ & $9(2.81)$ & $43(13.44)$ \\
\hline Total & & $260(81.26)$ & $60(18.74)$ & $320(100)$ \\
\hline
\end{tabular}

Source: Field survey, December 2019.

Table 2. Socioeconomic Characteristics of the Study Respondents

\begin{tabular}{llll}
\hline Variable code & Variable name and description & Mean & Mode category \\
\hline GEN & Gender (Male=1) & 0.81 & Male \\
\hline AGE & Age $(18-28=1)$ & 0.64 & $22-26$ \\
\hline HHS & Household size $(3-6=1)$ & 0.62 & 4 \\
\hline FMT & Family type (Joint=1) & 0.18 & Nuclear \\
\hline HHH & Household head (Male=1) & 0.93 & Male \\
\hline MAR & Marital status (Married=1) & 0.23 & Arranged marriage \\
\hline EDU & Educational level (Secondary/ Post-secondary=1) & 0.78 & Secondary education \\
\hline INC & Income per month (\$180-\$250) & 0.73 & US\$220-US\$230 \\
\hline EMP & Employment status (Employed=1) & 0.63 & Studying + working \\
\hline MAP & Membership in any programs (Member=1) & 0.36 & Nonmember \\
\hline FBG & Family background (Agricultural=1) & 0.83 & Agricultural \\
\hline FEN & Farming experience (5-10 years=1) & 0.45 & $5-10$ years \\
\hline FOI & Field of interest (Animal husbandry=1) & 0.36 & Plant science \\
\hline ABR & Respondent returned from abroad (Returned=1) & 0.23 & Non-gone abroad \\
\hline
\end{tabular}


US $\$ 230$. Less than three-fourths $(73 \%)$ had monthly earnings in the range of US $\$ 180-\mathrm{US} \$ 250$. More than three-fourths (77\%) of the youths are single, indicating that agriculture employs a many single youths, especially when farming is the major source of self-reliance and income. The results showed that $64 \%$ of the respondents do not belong to any agricultural program, while $36 \%$ are program members. Nearly two-thirds $(63 \%)$ were employed. Most family backgrounds of the respondents were agriculture (83\%). The study area was an agrarian community, so nearly half of the people already engaged in farming had a farming experience level of $5-10$ years (45\%). About $64 \%$ of the respondents were interested in crop production and $36 \%$ were interested in animal husbandry. Nearly one-fourth $(23 \%)$ of the respondents had traveled outside Nepal, while the remainder had never been abroad for work or study purposes.

\section{Agencies Involved in Empowering Youth in the Study Area \\ Farming is not always an easy or appealing career option, but an increasing number of youths are reorienting to farming as an entrepreneurial enter-}

prise through creative efforts (Young Professionals for Agricultural Development [YPARD] Nepal, 2019). Considering agriculture as a platform from which youths can be inspired to build professional paths, a number of government organizations (GOs), nongovernmental organizations (NGOs), and private agencies have implemented agricultural programs to increase youth engagement in agricultural work in Nepal. As noted above, $36 \%$ of the respondents belonged to such efforts. In the study area, youths are very active and have formed many organizations among themselves that work for common objectives. Milijuli (Together) is an agricultural organization formed by more educated youth with the intent to revolutionize agriculture with their skill and knowledge. YUWA is a specialized group of young farmers formed in the study area to solve agricultural problems jointly. The GOs in the study area that are providing support are governed by the Association of Youth Organizations Nepal (AYON), which acts as an umbrella organization for youth organizations to encourage cooperation, dialogue, networking, and collaboration. Some of the organizations are described in Table 3.

Table 3. Agencies Involved in Empowering Youth in the Study Area

\begin{tabular}{|c|c|c|}
\hline Agency & Date Established & Role \\
\hline We Inspire Nepal (WIN) & 2012 & $\begin{array}{l}\text { Inspire personal development; conduct motivational seminars and } \\
\text { trainings }\end{array}$ \\
\hline Change Fusion Nepal & 2008 & $\begin{array}{l}\text { Help youth direct their vision and skills through social entrepre- } \\
\text { neurship with four components: Mentorship, Knowledge, Funding, } \\
\text { and Networking }\end{array}$ \\
\hline YUWA & 2009 & $\begin{array}{l}\text { Promote youth participation through empowerment and advocacy, } \\
\text { work actively to develop youth-adult partnership in several areas }\end{array}$ \\
\hline Open Space Nepal & 1997 & $\begin{array}{l}\text { Unite youths and provide them with a platform to interact with } \\
\text { others, develop skills and take leadership; work to activate youth } \\
\text { through three areas of advocacy: media, education, and innovation }\end{array}$ \\
\hline Youth Initiative & 2001 & Develop youth potential, encourage positive change in society \\
\hline 4-H club & 2014 & $\begin{array}{l}\text { Promote youth-related awareness programs for self-employment and } \\
\text {-reliance at the community level in agriculture and economic efforts }\end{array}$ \\
\hline $\begin{array}{l}\text { Forum for Rural Welfare and Agri- } \\
\text { cultural Reform for Development } \\
\text { (FORWARD) }\end{array}$ & 1997 & $\begin{array}{l}\text { Improve food and nutrition security, household income and resource } \\
\text { conservation, integrate social mobilization, agriculture, livestock, } \\
\text { fisheries and aquaculture }\end{array}$ \\
\hline $\begin{array}{l}\text { Local Initiatives for Biodiversity, } \\
\text { Research and Development } \\
\text { (LI-BIRD) }\end{array}$ & 1995 & $\begin{array}{l}\text { Capitalize on local resources, innovations, and institutions for } \\
\text { sustainable management of natural resources for improving } \\
\text { livelihood of smallholder farmers }\end{array}$ \\
\hline
\end{tabular}

Source: Focus group discussion, 2019. 
Several other organizations and clubs were noted in the study areas, such as Baal Samaj Nepal (Children Society Nepal) in Tandi, Creative Youth Society (CYS) in Bardaghat, Friendship Youth Society (FYS) in Baseni, Deurali Youba Club (DYC) in Binayee Tribeni, Ideal Youth Group (IYG) in Bardaghat, and Buddha Youth Club (BYC) in Binayee Tribeni. In the Chitwan district, youth generally are getting the infrastructure that is needed for development. The multidisciplinary agencies have long been used by agriculture extension as a means to engage youth in economic, social, and agricultural development. Extension agents help in building relationships with potential collaborators, identifying shared interests of youth, and creating new opportunities to extend their work in ways that benefit community farmers. Among the study areas, Bardaghat in Nawalparasi West has the highest number of youth engaged in farming, likely due to the active role of youth organizations, extension services, and the interest of youth. While some youths are members of at least one agency in the study areas, most of them have not been a part of actual agricultural enterprise and programming.

\section{Level of Youth Involvement in Agro-Enterprises}

Although the youth population of the world is anticipated to increase substantially, employment and entrepreneurial opportunities for young people remain limited, especially in economically stagnant developing countries (Technical Centre for Agricultural and Rural Cooperation [CTA], 2017). Engaging rural youth in agribusiness has become an important strategy to create employment opportunities in Nepal. Not all young people are inspired by the notion that farming provides a productive career and profitable returns. The level of youth involvement in agro-enterprises varies with factors such as the opportunities available, their beliefs and attitudes, and location. Nevertheless, several studies have shown that the increasing profitability of agribusiness has attracted youth to agro-enterprises in many developing countries including Ghana (Banson, Nguyen, Bosch, \& Nguyen, 2015; Yeboah, Sumberg, Flynn, \& Anyidoho, 2017), Ethiopia (Bezu \& Holden, 2014; Tadele \& Gella, 2012), and Nigeria (Baumüller, 2018; Fawole \&
Olajide, 2012). The level of youth involvement in agro-enterprises in this study is shown in Table 4 and Figure 3.

Most youth are involved in crop production $(33.13 \%)$, horticulture $(15.31 \%)$, and cattle or buffalo rearing for meat and milk production $(10.00 \%)$ to sell in nearby markets. A notable share, about $9 \%$, were engaged in farming business: dealing with the entrepreneurship of their own firms, or agro-marketing (trading in agricultural goods). A relative few are involved in work such as farm labor, farm maintenance, and feed-processing industries. While it was found that the plurality of the youths in the study area is actively involved in crop production, their involvement in other sectors of agricultural enterprise needs to be encouraged.

\section{Economic and Personal Attitudes of Youth toward Farming}

Although agribusiness could be well-positioned to absorb youth and thus reduce unemployment, this has not been the case, as only one-third of the youth population is engaged in agriculture in Nepal (Central Bureau of Statistics Nepal, 2019).

Perceptions and behavioral attitudes play an important role in influencing enthusiasm of youth for farming. A youth decides to commence any sort of business activity primarily if it is perceived

\section{Table 4. Level of Youth Involvement in Agro- Enterprises}

\begin{tabular}{lrrr}
\hline Agro-enterprise Practice & Frequency & Percentage & Rank \\
\hline Crop production & 106 & 33.13 & 1 \\
Horticulture & 49 & 15.31 & 2 \\
Cattle or buffalo rearing & 32 & 10.00 & 3 \\
Farming business & 29 & 9.06 & 4 \\
Agro-marketing & 21 & 6.56 & 5 \\
Farm labor & 19 & 5.94 & 6 \\
Poultry & 15 & 4.69 & 7 \\
Goat rearing & 13 & 4.06 & 8 \\
Farm maintenance & 12 & 3.75 & 9 \\
Feed processing & 9 & 2.81 & 10 \\
Aquaculture & 7 & 2.19 & 11 \\
Piggery & 4 & 1.25 & 12 \\
Apiculture & 4 & 1.25 & 13 \\
\hline Total & 320 & 100 & \\
\hline
\end{tabular}


to be more profitable and feasible than alternatives (Liñán, Santos, \& Fernández, 2011).

A five-point Likert scale ( $1=$ Strongly disagree [SDA], 2=Disagree [DA], 3=Undecided [UD], $4=$ Agree $[\mathrm{A}], 5=$ Strongly agree $[\mathrm{SA}]$ ) was used to assess significant differences. Respondents were asked to choose different categories signifying different strengths of agreement and disagreement. This category was scored and the sum of the scores measures youth attitudes toward agriculture. The personal and economic attitudes toward farming of the study subjects are tabulated in Table 5 .

The average scale value is the index which determines the overall attitudes of youth toward farming, calculated by the following formula:

$\left.\mathrm{AVS}=\sum\{(\mathrm{Si} * \mathrm{fi}) / \mathrm{N}) / 5\right\}$

AVS=average value scale

$\sum=$ summation

$\mathrm{Si}=$ scale value

$\mathrm{Fi}=$ frequency of importance given by farmers

$\mathrm{N}=$ total number of interviewed youth (320)

Most respondents strongly agree with the idea of a positive role for agriculture in the development of society. At the same time, however, farming is perceived as a burdensome occupation to be engaged in. The majority agreed that farming is an acceptable way of life to them, disagreeing with the statement "Farming reduces one's prestige in society." Farming is considered not only for the aged, less privileged, and uneducated, but also as appropriate for educated youths. Most youths agreed that farming creates employment and is a successful enterprise. Yet, most of them do not perceive farming as a beneficial venture. To them, returns from farming are unattractive; they view farming as a low-income profession.

\section{What Attracts Youth to Agriculture?}

Agriculture tends to attract young people when it is perceived as "profitable, competitive, and dynamic" (Kaini, 2019, para. 3). The factors determined in this study that attract youth to agriculture are shown in Table 6.

Most youths are actively engaged in agriculture due to the absence of other desirable job opportunities or because they originate from agricultural family backgrounds. The personal reasons that guide youth toward agriculture include the high value placed on family land ownership and the value placed on being self-employed; only a few are involved in agriculture with the aim of providing jobs for others. Some (about 4\%) intentionally

\section{Figure 3. Level of Youth Involvement in Agro-Enterprises}

The red bar represents the percentage of each category of engagement field; the blue bar represents the number of respondents $(N=320)$.

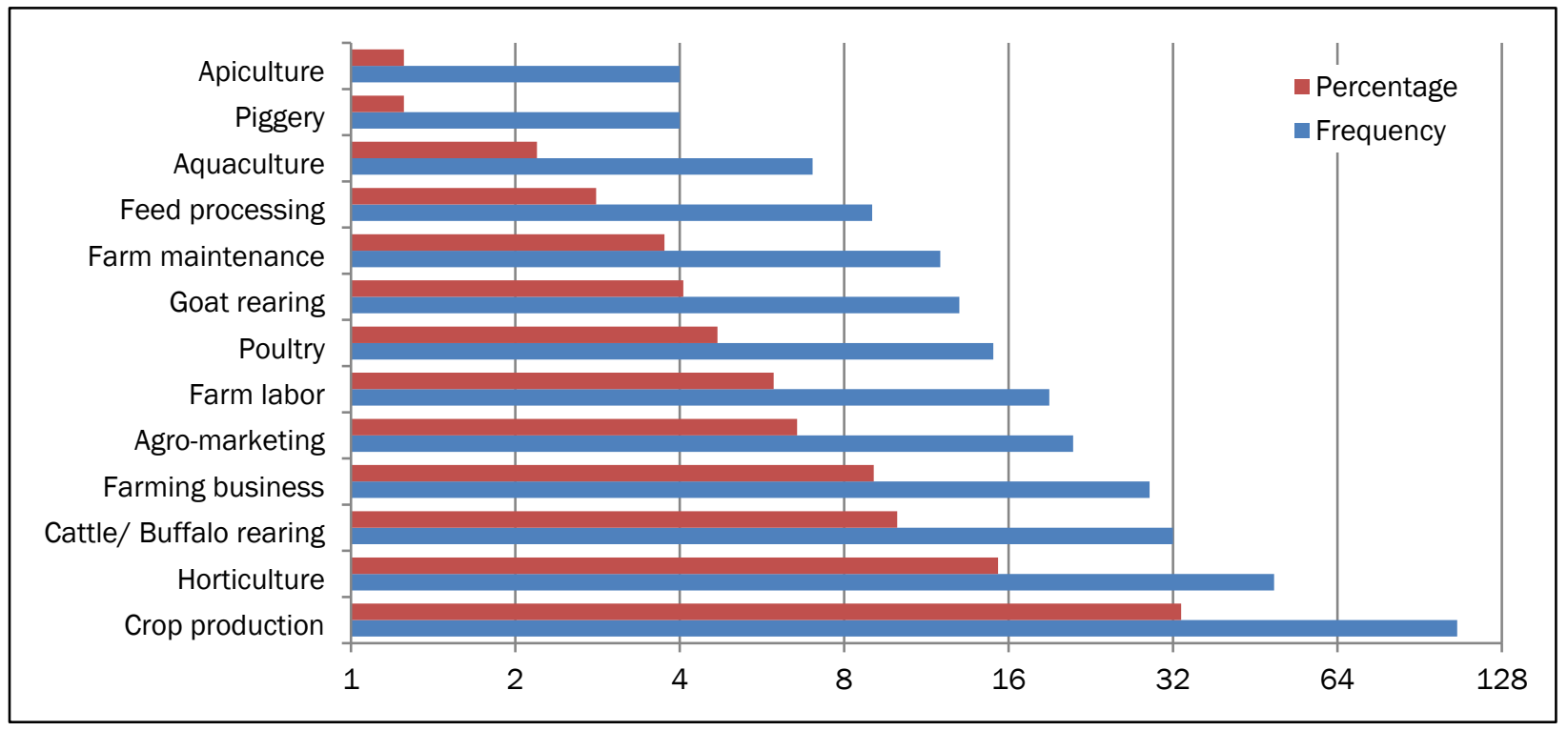


want to get involved due to a heart-felt "passion." Very few $(1.25 \%)$ are motivated through being agricultural graduates; for this reason, they choose farming over other careers. Some youths are engaged in agribusiness due to perceiving a good deal of opportunity for young entrepreneurs: $8.75 \%$ and $7.19 \%$ are involved due to opportunities for various forms of agribusiness.

Constraints Faced by Youth in Transforming the Economy Through Agriculture

Various constraints hold back the development of youth engagement in agriculture in many developing countries, including Nepal. Social, economic, and technological constraints faced by youth in farming are ranked and shown in Table 7.

Major social constraints to active participation in agriculture are society's overall perception of farmers, followed by lack of support from the government, poor basic farming knowledge and inadequate access to extension facilities, and less respect for

\section{Table 6. Factors that Attract Youth to Agriculture}

\begin{tabular}{llrc}
\hline S. N & Statements of Reasons & Frequency & Percentage \\
\hline I. & Psychological reasons & & \\
1 & Absence of other desirable job opportunities & 54 & 16.88 \\
2 & Agricultural family background & 48 & 15.00 \\
3 & High value of land ownership & 32 & 10.00 \\
4 & Self-employment & 29 & 9.06 \\
5 & To provide jobs to others & 9 & 2.81 \\
6 & Feel passion for agriculture & 13 & 4.06 \\
7 & Farming is not a risky practice & 11 & 3.44 \\
8 & Agricultural graduate & 4 & 1.25 \\
\hline II. & Economic reasons & & \\
1 & Many opportunities for young entrepreneurs & 28 & 8.75 \\
2 & Opportunities for business in agriculture & 23 & 7.19 \\
3 & Credit acquisition opportunities & 10 & 3.13 \\
4 & Poverty alleviation & 16 & 5.00 \\
5 & As a profession for side-earning & 32 & 10.00 \\
6 & Offers profitable returns & 11 & 3.44 \\
& Total & 320 & 100 \\
\hline
\end{tabular}

Table 5. Attitude of Youth Toward Agriculture $(N=320)$

\begin{tabular}{lrrrrrrr}
\hline Statements & SA 5 & A 4 & UD 3 & DA 2 & SDA 1 & $\begin{array}{c}\text { Average } \\
\text { scale value }\end{array}$ & Rank \\
\hline I. Personal attitudes & & & & & & & \\
Agriculture contributes to rural development & 220 & 96 & 4 & - & - & 0.83 & 1 \\
Farming is burdensome & 98 & 84 & 48 & 42 & 48 & 0.61 & 2 \\
Farming is the acceptable way of life to me & 65 & 84 & 70 & 57 & 44 & 0.57 & 3 \\
Farming reduces one's prestige in society & 63 & 48 & 16 & 144 & 49 & 0.50 & 4 \\
Farming is for aged people & 45 & 48 & 19 & 153 & 55 & 0.46 & 5 \\
Farming is for the less privileged & 38 & 42 & 26 & 166 & 48 & 0.45 & 6 \\
Farming is for uneducated people & 13 & 28 & 68 & 96 & 115 & 0.38 & 7 \\
\hline II. Economic attitudes & & & & & & & \\
Farming creates employment & 148 & 84 & 23 & 30 & 35 & 0.69 & 1 \\
Farming is a successful enterprise & 67 & 62 & 48 & 70 & 73 & 0.52 & 2 \\
Farming is a beneficial venture & 63 & 58 & 26 & 107 & 66 & 0.50 & 3 \\
Farming return is attractive & 48 & 56 & 21 & 121 & 74 & 0.47 & 4 \\
Farming generates low income & 45 & 48 & 13 & 150 & 64 & 0.46 & 5 \\
\hline
\end{tabular}


Table 7. Constraints Faced by Youth in Transforming the Economy Through Agriculture

\begin{tabular}{|c|c|c|c|c|c|c|c|c|}
\hline & Statement of Problems & SA 5 & A 4 & UD 3 & DA 2 & SDA 1 & $\begin{array}{c}\text { Average } \\
\text { scale value }\end{array}$ & Rank \\
\hline \multirow[t]{6}{*}{ I } & Social constraints & & & & & & & \\
\hline & People's perception of farmers & 123 & 86 & 20 & 52 & 39 & 0.73 & 1 \\
\hline & Lack of incentives from government & 98 & 86 & 16 & 64 & 56 & 0.67 & 2 \\
\hline & Poor basic farming knowledge & 98 & 73 & 14 & 80 & 55 & 0.65 & 3 \\
\hline & Access to extension facilities & 56 & 83 & 31 & 81 & 69 & 0.59 & 4 \\
\hline & Young farmers are less respected in society & 70 & 57 & 26 & 78 & 89 & 0.56 & 5 \\
\hline \multirow[t]{7}{*}{ II } & Economic constraints & & & & & & & \\
\hline & Inadequate credit provision & 124 & 98 & 28 & 40 & 30 & 0.76 & 1 \\
\hline & High cost of transportation & 92 & 106 & 18 & 64 & 40 & 0.69 & 2 \\
\hline & Inappropriate insurance and taxation policies & 88 & 93 & 23 & 69 & 47 & 0.67 & 3 \\
\hline & Low prices of products & 83 & 93 & 9 & 75 & 60 & 0.64 & 4 \\
\hline & Access to markets & 63 & 93 & 24 & 82 & 58 & 0.61 & 5 \\
\hline & Poor returns on investment & 59 & 71 & 16 & 92 & 82 & 0.59 & 6 \\
\hline \multirow[t]{6}{*}{ III } & Technological constraints & & & & & & & \\
\hline & Poor access to advanced ICT innovations & 92 & 117 & 19 & 65 & 27 & 0.71 & 1 \\
\hline & Storage facilities & 86 & 104 & 28 & 63 & 39 & 0.68 & 2 \\
\hline & Unavailability of modern machinery & 84 & 102 & 23 & 64 & 47 & 0.67 & 3 \\
\hline & Lack of input processing units & 70 & 97 & 34 & 64 & 55 & 0.64 & 4 \\
\hline & Irrigation deficits & 68 & 79 & 12 & 96 & 65 & 0.59 & 5 \\
\hline
\end{tabular}

Table 8. Youth Contribution to Agro-Economic Transformation

\begin{tabular}{lcc}
\hline Overall contribution level of youth & Frequency $(\boldsymbol{N}=\mathbf{3 2 0})$ & Percentage \\
\hline High & 109 & 34 \\
Medium & 67 & 21 \\
Low & 144 & 45 \\
Total & 320 & 100 \\
\hline
\end{tabular}

constraints, followed by unavailability of storage facilities and modern machinery, lack of input processing units, and irrigation deficits.

\section{Youth Contribution to Agro-Economic Transformation \\ The level of personal contribution to economic transformation was self-}

kets, and poor returns on investment. Difficulty with obtaining credit is due mainly to high interest rates, which reflect both transitional issues of economic transformation and structural problems with agriculture. Lack of side-business support (e.g., lack of financial support from non-agricultural business, low profitability, and macroeconomic uncertainty) makes banks view the agricultural sector as a high risk for loans. (Open Space Nepal and Change Fusion Nepal are working to make credit more accessible to young farmers.) Inadequate access to advanced information and communication technology (ICT) ranked first among the technological determined by the respondents, taking into account problems and strengths. Economic transformation, as used in this study, means a higher average income, broader diversity of economic enterprises, and greater contribution to GDP through agriculture. Table 8 shows the self-perceived levels of the contribution of respondents to building the economy through transforming the agricultural system.

Nearly half of the respondents (45\%) were found to have a low level of contribution to economic transformation through farm involvement, and $34 \%$ and $21 \%$ of the respondents had a high and a medium level of contribution, respectively. 


\section{Conclusions and Suggestions}

There are many psychological, economic, and social factors that attract youth to farming, and most youth have a positive perception of farming; thus, the number of youth engaged in agriculture is increasing. Due to the absence of alternative desirable job opportunities in the country and/or to having originated from an agricultural family, a large number of youths are willingly or unwillingly engaged in agricultural profession. The majority are primarily involved in horticultural crop production and animal rearing, which generates direct, attractive returns and thus increases youth enthusiasm toward agriculture. This positive attitude makes youth more engaged in agricultural enterprises that contribute to the economic development of Nepal.

Nevertheless, their contribution to economic growth remains well below its potential. Several constraints limit youth participation in the agriculture sector. Major challenges include inadequate access to credit, a low social perception of farmers, limited access to advanced ICT innovations, and high costs of transportation. GOs, NGOs, youth development agencies, United Nations organizations concerned with agriculture (e.g., the Food and Agriculture Organization [FAO], International Fund for Agricultural Development [IFAD]), and youth organizations primarily operated by youth (e.g., YUWA, Open Space Nepal) should provide support and incentives such as banking and credit facilities, subsidized agricultural inputs such as seed, fertilizers, and pesticides, and extension services to nurture and sustain youth in agricultural professions.

There needs to be an augmentation of knowl- edge of basic farming practices among youth by developing agricultural training programs and strengthening existing ones. Efforts are needed that focus on a broad variety of agricultural economic contributions: not only crop production, horticulture, and cattle rearing, but farming business and agro-marketing as well. Agricultural science and entrepreneurship programs should be made widely available and strongly encouraged among students. GOs and NGOs can play facilitating roles by developing programs such as pension plans, crop and livestock insurance, and managed market infrastructure. Youth who are currently in the agricultural professions should be motivated, encouraged, and honored so that others will take a stronger interest in farming, and promote agricultural and economic transformation in Nepal. Investment, training, and extension programs in Nepal have been limited in scope. Future work on youth empowerment and involvement in agriculture should be motivation-based. Initiatives such as networking and partnerships that encourage youth to enter farming professions should be developed. It is hoped that the findings of this paper present clear insights into efforts that will foster effective community transformation through agricultural development.

\section{Acknowledgments}

The authors owe their sincere and deep gratitude to Subodh Gyawali and Arjun Rawal from the Institute of Forestry, Tribhuvan University, for their continuous support throughout this research. Special thanks to our parents, whose guidance is always with us.

\section{References}

Adedoyin, S., \& Jibowo, A. (2005). Youth and children programmes in Nigeria. In Agricultural Extension in Nigeria, Agricultural Extension Society of Nigeria (AESON).

Allen, A., Howard, J., Kondo, M., Jamison, A., Jayne, T., Snyder, J. ... \& Yeboah, K. F. (2016). Agri-food youth employment and engagement study (AGYEES). East Lansing: Michigan State University. Retrieved from https://gcfsi.isp.msu.edu/files/2215/3306/7552/AgYees Report FINAL web from-ISP.pdf

Aphunu, A., \& Atoma, C. N. (2010). Rural youths' involvement in agricultural production in Delta Central Agricultural Zone: Challenge to agricultural extension development in Delta State. Journal of Agricultural Extension, 14(2), 46-55. https://doi.org/10.4314/jae.v14i2.64123

Banson, K. E., Nguyen, N. C., Bosch, O. J., \& Nguyen, T. V. (2015). A systems thinking approach to address the complexity of agribusiness for sustainable development in Africa: A case study in Ghana. Systems Research and Behavioral Sciences, 32(6), 672-688. https://doi.org/10.1002/sres.2270 
Baumüller, H. (2018). The little we know: An exploratory literature review on the utility of mobile phone-enabled services for smallholder farmers. Journal of International Development, 30(1), 134-154. https://doi.org/10.1002/jid.3314

Bezu, S., \& Holden, S. (2014). Are rural youth in Ethiopia abandoning agriculture? World Development, 64, 259-272. https://doi.org/10.1016/j.worlddev.2014.06.013

Breitenbach, M. (2006). A model for rural youth participation in local government: A South African case study. Annals of Child and Youth Studies, 1(1), 72-84.

Bruton, G. D., Ketchen, Jr., D. J., \& Ireland, R. D. (2013). Entrepreneurship as a solution to poverty. Journal of Business Venturing, 28(6), 683-689. https://doi.org/10.1016/j.jbusvent.2013.05.002

Central Bureau of Statistics Nepal. (2019). Central Bureau of Statistics. Kathmandu: Government of Nepal, National Planning Commision. Retrieved from http://old.cbs.gov.np/sectoral statistics/social statistics

Chaudhary, D. (2018). Agricultural policies and rural development in Nepal: An overview. Research Nepal Journal of Development Studies, 1(2), 34-46. https://doi.org/10.3126/rnids.v1i2.22425

Díaz-Pichardo, R., Cantú-González, C., López-Hernández, P., \& McElwee, G. (2012). From farmers to entrepreneurs: The importance of collaborative behavior. The Journal of Entrepreneurship, 21(1), 91-116. https://doi.org/10.1177/097135571102100104

Fatunla, G. T. (1996). Socio-economic issues in the education of children of migrant fishermen in Nigeria. Journal of Sustainable Agriculture, 9(1), 31-61. https://doi.org/10.1300/J064v09n01 05

Fawole, O. P., \& Olajide, B. R. (2012). Awareness and use of information communication technologies by farmers in Oyo State, Nigeria. Journal of Agriculture and Food Information, 13(4), 326-337. https://doi.org/10.1080/10496505.2012.717003

Fletcher, A. (2019, December 28). Youth and economics [Blog post]. Youth + Social change. Retrieved from https://adamfletcher.net/category/adam-fletcher/

Gebremariam, E. B. (2017). The politics of youth employment and policy processes in Ethiopia. Institute of Development Studies [IDS] Bulletin, 48(3), 33-50. https://doi.org/10.19088/1968-2017.125

Guerra, N. G., \& Bradshaw, C. P. (2008). Linking the prevention of problem behaviors and positive youth development: Core competencies for positive youth development and risk prevention. New Directions for Child and Adolescent Development, 122, 1-17. https://doi.org/10.1002/cd.225

Gwanya , T. (2008). Address by the Director General at the launch of Youth In Agriculture and Rural Development. Western Cape Department of Land Affairs, ZA: Goudini Spa.

Haber, W. (2007). Energy, food, and land-The ecological traps of humankind. Environmental Science and Pollution Research, 14(6), 359-365. https://doi.org/10.1065/espr2007.09.449

Hartley, S. (2014). Collective learning in youth-focused co-operatives in Lesotho and Uganda. Journal of International Development, 26(5), 713-730. https://doi.org/10.1002/jid.3000

Hosein, N. A., \& Yadav, P. (2017). Youth involvement in the peaceful and sustainable development of Nepal. Kathmandu, Nepal: United Nations Peace Fund Nepal (UNPFN). Retrieved from https://www.np.undp.org/content/nepal/en/home/library/sustainable-development-goals-national-report--nepal/youth-involvement-in-the-peaceful-and-sustainable-development-of-Nepal.html

International Organization for Migration. (2016). Securing women's land and property rights in Nepal. Geneva, CH: IOM. Retrieved from https://www.iom.int/news/securing-womens-land-and-property-rights-nepal

Jabed, M. (2016, March 06). Agricultural transformation. The Kathmandu Post. Retrieved from https://kathmandupost.com/opinion/2016/03/06/agricultural-transformation

Kaini, B. R. (2019, September 15). How to attract young people to farming? República (Kathmandu, NP). Retrieved from https://myrepublica.nagariknetwork.com/news/how-to-attract-young-people-to-farming/

Khanal, S., \& Shrestha, M. (2019). Agro-tourism: Prospects, importance, destinations and challenges in Nepal. Archives of Agriculture and Environmental Science, 4(4), 464-471. http://doi.org/10.26832/24566632.2019.0404013

Lawal, W. A. (2011). An analysis of government spending on agriculture sector and its contribution to GDP in Nigeria. International Journal of Business and Social Science, 2(20), 244-250. 
Leavy, J., \& Smith, S. (2010). Future farmers: Youth aspirations, expectations and life choices (Discussion paper 13). Brighton, UK: University of Sussex, Future Agricultures Consortium. Retrieved from https://www.ids.ac.uk/download.php?file=files/dmfile/FAC Discussion Paper 013FutureFarmers.pdf

Liñán, F., Santos, F. J., \& Fernández, J. (2011). The influence of perceptions on potential entrepreneurs. International Entrepreneurship and Management Journal, 7(3), 373-390. http://doi.org/10.1007/s11365-011-0199-7

Mogues, T., Yu, B., Fan, S., \& McBride, L. (2012). The impacts of public investment in and for agriculture: Synthesis of the existing evidence (ESA Working Paper No. 12-07). Rome: Food and Agriculture Organization of the UN, Agricultural Development Economics Division. Retrieved from http://www.fao.org/3/a-ap108e.pdf

Nepal Government Ministry of Youth and Sports. (2015). Youth vision-2025 and Ten-Year Strategic Plan. Kathmandu, Singha Durbar: Nepal Government. Retrieved from http://moys.gov.np/sites/default/files/nitiheru/Youth\%20Vision-2025.pdf

Nhamo, N., \& Chikoye, D. (2017). Models supporting the engagement of the youth in smart agricultural enterprises. In D. Chikoye, T. Gondwe, \& N. Nhamo (Eds.), Smart technologies for sustainable smallholder agriculture: Upscaling in developing countries (pp. 211-232). London \& San Diego, CA: Academic Press.

Proctor, F., \& Lucchesi, V. (2012). Small-scale farming and youth in an era of rapid rural change. London \& The Hague: International Institute for Environment and Development/HIVOS. Retrieved from https://pubs.iied.org/pdfs/14617IIED.pdf

Raju, D., \& Rajbhandary, J. (2018). Youth employment in Nepal (English). Washington, DC: World Bank Group, International Development In Focus. Retrieved from http://documents.worldbank.org/curated/en/816461530076091272/Youth-employment-in-Nepal

Roepstorff, T. M., Wiggins, S., \& Hawkins, A. M. (2011). The profile of agribusiness in Africa. In K. Yumkella, P. Kormawa, T. M. Roepstorff, \& A. M. Hawkins (Eds.), Agribusiness for Africa's Prosperity (pp. 38-56). Vienna: United Nations Industrial Development Organization (UNIDO).

Franklin Delano Roosevelt Foundation, The. (n.d.). The Roosevelt Scholars. Cambridge, MA: The FDR Foundation. Retrieved on April 27, 2020, from https:/ /fdrfoundation.org/the-roosevelt-scholars-program/

Sinyolo, S., \& Mudhara, M. (2018). The impact of entrepreneurial competencies on household food security among smallholder farmers in KwaZulu Natal, South Africa. Ecology of Food and Nutrition, 57(2), 71-93. https://doi.org/10.1080/03670244.2017.1416361

Statista. (2020). Nepal: Youth unemployment rate from 1999 to 2019 [Chart]. Hamburg, DE: Statista. Retrieved from https://www.statista.com/statistics/812273/youth-unemployment-rate-in-nepal/

Tadele, G., \& Gella, A. A. (2012). 'A last resort and often not an option at all': Farming and young people in Ethiopia. Institute of Development Studies [IDS] Bulletin, 43(6), 33-43. https://doi.org/10.1111/j.1759-5436.2012.00377.x

Technical Centre for Agricultural and Rural Cooperation [CTA]. (2017, May 12). Youth in agribusiness: Shaping the future of agriculture [Blog post]. Wageningen, NL: Technical Centre for Agricultural and Rural Cooperation (CTA). Retrieved from https://www.cta.int/en/youth/all/article/youth-in-agribusiness-shaping-the-future-of-agriculturesid0d4ef275f-450a-4fa0-87d0-1a7b18506632

The Rising Nepal. (2014). Youths and agriculture. The Rising Nepal. Retrieved from http://therisingnepal.org.np/news/12657

United Nations. (2008). Achieving sustainable development and promoting development cooperation (UN Publication No. E.08.II.A.11). New York: United Nations Department of Economic and Social Affairs. Retrieved from https://www.un.org/en/ecosoc/docs/pdfs/fina_08-45773.pdf

United Nations. (2018). World youth report: Youth and the 2030 agenda for sustainable development. Chapter 3, Youth employment (UN Publication No. E.18.IV.7). New York: United Nations Department of Economic and Social Affairs. Retrieved from https://www.un.org/development/desa/youth/wp-content/uploads/sites/21/2019/02/chapter3wyr-2030agenda.pdf

Yeboah, T., Sumberg, J., Flynn, J., \& Anyidoho, N. A. (2017). Perspectives on desirable work: Findings from a Q study with students and parents in rural Ghana. European Journal of Development Research, 29(2), 423-440.

https://doi.org/10.1057/s41287-016-0006-y

Young Professionals for Agricultural Development [YPARD] Nepal. (2019, July). YPARD Nepal. Rome: YPARD. Retrieved from https://ypard.net/country/nepal 